\title{
Formas de ação coletiva: reflexões a partir dos conflitos por terra em Magé, RJ
}

Marco Antonio Teixeira'

\begin{abstract}
Resumo
Este trabalho analisa as formas de ação coletiva empregadas por um grupo de trabalhadores rurais para conquistarem a desapropriação das terras onde viviam. A análise se baseia nos conflitos por terra envolvendo posseiros e grileiros da gleba América Fabril e Fazenda Conceição de Suruí, em Magé, no Rio de Janeiro. A maior parte da disputa - entre 1960 e 1970 - foi durante o regime civil-militar, período considerado por parte dos estudiosos como de desmobilização política. O caso analisado se destaca entre os demais conflitos fundiários da época porque os trabalhadores rurais conseguiram a desapropriação das terras em 1973 e 1974, respectivamente, e estas foram as únicas desapropriações decorrentes de conflitos no estado entre o golpe de 1964 e o fim dos anos 1970 que têm registro até o momento.
\end{abstract}

Palavras-chave: Ação coletiva. Trabalhadores rurais. Conflitos por terra. Ditadura civil-militar. Rio de Janeiro.

\section{Introdução}

Sindicatos e federações fechados. Lideranças e trabalhadores rurais perseguidos, presos, exilados, mortos. O líder das Ligas Camponesas, o advogado Francisco Juliāo, exilou-se $e^{2}$. O mesmo destino teve o fundador da União dos Lavradores e Trabalhadores Agrícolas do Brasil (Ultab) e da Confederação Nacional dos Trabalhadores na Agricultura (Contag), Lyndolpho Silva. Manoel da Conceição, líder dos posseiros em Pindaré-Mirim (MA) foi preso nove

I Mestre em Ciências Sociais. Cursando atualmente doutorado em Sociologia pelo Instituto de Estudos Sociais e Políticos (IESP) da Universidade do Estado do Rio de Janeiro (UERJ), com bolsa da Fundação Carlos Chagas Filho de Amparo à Pesquisa do Estado do Rio de Janeiro (FAPERJ).E-mail: mateixeira@gmail.com

2 Versão revisada de artigo originalmente apresentado no XVI Congresso Brasileiro de Sociologia, realizado entre 10 e 13 de setembro de $2013 \mathrm{em}$ Salvador (BA), e que foi escrito com base em Teixeira (20I I). 
vezes e barbaramente torturado. Manoel Mangueira foi assassinado em sua posse na área chamada Campos Novos, abrangendo parte do município de São Pedro da Aldeia e Cabo Frio, em 19713. A repressão aos movimentos de trabalhadores rurais na ditadura civil-militar foi grande, a ponto de desarticular lutas que se desenrolavam há anos no país. Mesmo assim, um grupo de trabalhadores rurais de Magé, na Baixada Fluminense, lutou pelo direito de permanecer na terra que ocupava e se transformou em um exemplo de resistência no período em todo estado do Rio de Janeiro. Nesse processo, pessoas se conformaram e se constituíram em posseiros e grileiros. O objetivo desse trabalho é analisar as formas de ação coletiva desse grupo de trabalhadores rurais na luta pela conquista da terra.

$\mathrm{Na}$ literatura sobre conflitos fundiários no Brasil, um número significativo de estudos encerra suas análises em 1964 ou as inicia já nos anos 1980. As lutas sociais no campo, portanto, foram pouco pesquisadas no período pós-golpe de 1964 e pré-redemocratização, no fim dos anos 1970 e início dos anos 1980. Esse intervalo temporal vem sendo identificado pela bibliografia como de desarticulação das lutas dos trabalhadores rurais. Mas há autores que apontam que as lutas continuaram a existir de forma latente em algumas situações, algumas vezes com novos contornos, ganhando força quando era possível. Por isso, esse trabalho vai analisar como as lutas no campo se desenrolaram após 1964 e durante a década de 1970 a partir de um estudo de caso.

Algumas reflexões de Palmeira (2009) contribuem para o entendimento do silêncio na literatura sobre lutas sociais em relação a alguns períodos. Segundo o antropólogo, entre os pesquisadores, há uma tendência em privilegiar a reflexão sobre as lutas sociais em seus momentos mais críticos, enquanto os momentos menos espetaculares tendem a ser esquecidos. "A própria existência da luta costuma ser vinculada aos seus momentos de maior intensidade. Fora dali, ela é considerada inexistente" (PALMEIRA, 2009, p. 172). Assumir essa postura significa, para o autor, aceitar um recorte dos fatos que esconde a existência dos conflitos e, consequentemente, exclui da hierarquia dos objetos de conhecimento um conjunto de experiências vividas pelas classes trabalhadoras.

3 Casos como esses ocorreram em diferentes locais do pais. Para obter mais detalhes, ver Carneiro e Cioccari (20/0). 
Nesse sentido, estudar casos de lutas por terra durante a ditadura civil-militar é uma tentativa de contribuir para romper com parte do silêncio na literatura sobre as lutas sociais no campo no período, trazendo pistas para pensar como foi a experiência dos trabalhadores rurais em luta pela terra na ocasião. E, para desenvolver esse artigo, algumas noçóes foram fundamentais; por isso, serão analisadas a seguir.

A primeira das noçóes refere-se à frguração, formulação do sociólogo alemão Norbert Elias, que propóe seu emprego como forma de superar o problema tradicional na sociologia: a separação entre indivíduo e sociedade (ELIAS, 1994; 1995; 2006; 2008). Figuração é um conceito utilizado para evitar a ideia de que pessoas e sociedade são substancialmente diferentes. A compreensão dos grupos humanos, pequenos ou grandes, como figuraçốes que os seres humanos formam entre si, permite um melhor ajustamento dos conceitos aos dados observáveis do que a habitual polarização do indivíduo e da sociedade. Com esse conceito Elias propóem um deslocamento da perspectiva do observador: ao invés de olhar as pessoas que constituem um grupo ou o grupo que elas formam entre si, trata-se de observar as figuraçôes de seres humanos.

Por meio do conceito de figuração, Elias (1994; 1995; 2006; 2008) apresenta uma perspectiva relacional, recusando a concepção do homo clausus, ou seja, do indivíduo isolado. Para o sociólogo, o indivíduo é parte da rede de relações (figuração). Essa é marcada pela interdependência entre os indivíduos. É sob essa perspectiva que este artigo procura entender a ação dos trabalhadores rurais; afinal, as açôes coletivas destes são compreendidas em relaçáo aos movimentos dos supostos proprietários que reivindicavam as terras que foram ocupadas, assim como em relação aos demais agentes que se envolveram no caso, como o Estado (mediante suas diferentes instâncias), o movimento sindical e advogados.

Outra perspectiva que orienta esse estudo é a ênfase à experiência dos trabalhadores, conforme Thompson (1987) e Comerford (1999). Ao se referir às experiências vividas pelos trabalhadores rurais como lutas, Comerford mostrou como "[...] os agentes constroem culturalmente o sentido dessas experiências e também representaçóes sobre a sua própria pessoa, sobre as suas açôes, sobre a sua comunidade, e sobre as suas instituiçóes" (COMERFORD, 
1999, p. 43). Enfatizar a experiência de homens e mulheres e a elaboração que esses sujeitos fazem da sua história significa acentuar os papéis desses atores na história.

A leitura de Thompson (1998) foi importante, também, para a construção de uma perspectiva que permite ver formas alternativas de ação política. $\mathrm{O}$ historiador inglês, em um estudo no qual analisa alguns motins de fome ocorridos na Inglaterra no século XVIII, mostrou que há diversas formas de ação coletiva alternativas à rebelião, comumente identificada como a mais óbvia. Entre elas, "[...] petiçóes em massa junto às autoridades, jejum, sacrifícios e oraçóes, inspeções até as casas dos ricos ou migração de aldeias inteiras" (THOMPSON, 1998, p. 206). Orientar o olhar para perceber as diferentes formas de ação coletiva que as lutas podem assumir é fundamental para uma compreensão mais complexa das lutas sociais e valorização das diferentes contribuiçôes dos sujeitos sociais que participaram das lutas de variadas maneiras.

Ademais, foi fundamental, na leitura do trabalho de Thompson (1998) - e essa questáo está relacionada à anterior -, a interpretaçáo que não eram apenas elementos econômicos os motivadores para as açóes populares. Logo, pôde-se perceber a importância da multiplicidade de motivaçóes que levam os atores a agir nas lutas sociais. No caso estudado por Thompson (1998), o motim de fome na Inglaterra do século XVIII, o motivo para o desencadeamento das açóes diretas era a manutenção dos costumes, que o autor chama de "economia moral dos pobres". O autor mostra, ainda, que essa economia moral não tinha implicações só nos momentos de perturbação social, mas influenciava, de forma geral, o governo e o pensamento do século XVIII (THOMPSON, 1998).

Outros autores foram importantes para a construção da perspectiva desse trabalho sobre ação coletiva. Na literatura sobre o conceito, Honneth (2003) e Melucci (2001) reforçaram a concepção de que os estudos sobre ação coletiva devem analisar não só os interesses pragmáticos e racionais dos sujeitos que agem mas também os aspectos culturais e morais. Sobre esse aspecto, Honneth (2003) chama a atençáo para o fato de que a luta social não tem como ponto de partida apenas interesses, mas sim sentimentos morais de injustiça e destaca que as novas tendências da historiografia podem revelar o nexo firmado entre desrespeito moral e luta social ${ }^{4}$. E afirmar isso não significa considerar

4 Honneth (2003) cita os trabalhos de E. P. Thompson, Barrington Moore e Andreas Griebinger como as primeiras comprovações empíricas dessa tese. 
que todos os confrontos sociais sejam produto de um mesmo modelo de luta por reconhecimento moral.

Muitos casos históricos já mostraram que a segurança da sobrevivência econômica motivou o protesto e a rebeliáo em massa. Saber se, em linhas gerais, o conflito social segue a lógica da persecuçấo de interesses, a lógica da formação da reação moral, ou mesmo entender como esses elementos se combinam, permanece como questão empírica. $\mathrm{O}$ que não se deve evitar é deter a teoria social na dimensão do interesse, pois isso obstruiria a visão do significado social dos sentimentos morais.

Melucci (2001), por sua vez, chama a atenção para a composição dos fenômenos coletivos, feitos de motivaçóes, formas de relação, orientaçôes diversas. Com isso, desloca para o passado a concepção de que cabe somente às estruturas produzir transformaçóes, ignorando os modos de construir, individual e coletivamente, a mesma experiência humana. Para ele, a transformação também deve se operar nas mentes, nos afetos e nas emoçóes. Melucci (1991) destaca que a açáo dos movimentos está estreitamente relacionada com a vida cotidiana e com a experiência individual. $\mathrm{O}$ que se apreende aqui das proposiçóes desse autor, e que é central para esse trabalho, é a forma como ele examina a vida social, considerando-a em relação com as dimensões individuais e a experiência subjetiva.

Outro autor importante para a perspectiva desse estudo é Scott (2002), que destaca a importância de se estudar os aspectos cotidianos da luta como uma forma de compreender melhor os conflitos sociais e a resistência. Para Scott, a história dos eventos e das insurreiçóes camponesas ou dos trabalhadores fabris dedicadas inteiramente a greves gerais e a protestos, por mais importantes e sintomáticas que possam ser, não revela muito sobre a esfera mais durável dos conflitos de classes e da resistência, como "[...] a luta mais cotidiana levada na fábrica pela jornada de trabalho, pelo direito ao lazer, pelo salário, pela autonomia, por direitos e por respeito" (SCOTT, 2002, p. 11). Scott (2002, p. 11) acrescenta que, no caso dos "[...] trabalhadores que operam, por definição, numa desvantagem estrutural e sujeitos à repressão, tais formas de lutas cotidianas podem ser a única opçáo [de resistência] disponível”. O autor entende por formas cotidianas de resistência "[...] a luta prosaica, mas constante entre os camponeses e aqueles que querem extrair deles o trabalho, o alimento, os impostos, os aluguéis e os lucros" (SCOTT, 2002, p. 11). 
Em suma, o diálogo com Elias (1994; 1995; 2006; 2008), Comerford (1999), Thompson (1987; 1998), Melucci (2001), Honneth (2003) e Scott (2002) conformou a perspectiva desse trabalho. A literatura citada alertou para a importância em considerar a "experiência dos sujeitos" (COMERFORD, 1999; THOMPSON, 1987), as "variadas formas" que as açóes coletivas podem assumir em um dado conflito social (THOMPSON, 1998; HONNETH, 2003), a relevância de se considerar a "subjetividade dos atores em luta” (MELUCCI, 2001), assim como seus "aspectos cotidianos" (SCOTT, 2002). Além disso, o "olhar figuracional” (ELIAS, 1994; 1995; 2006; 2008) foi fundamental para a adoçáo de uma perspectiva relacional na pesquisa.

\section{Sujeitos, cenário e contexto}

O estudo empírico foi feito na gleba América Fabril ${ }^{5}$ e Fazenda Conceição de Suruí, áreas próximas entre si e localizadas no município de Magé, Baixada Fluminense ${ }^{6}$. Essas áreas foram ocupadas entre fins dos anos $1950 \mathrm{e}$ início dos anos 1960 por pessoas oriundas de diferentes locais do estado do Rio de Janeiro, mas também do Espírito Santo, Minas Gerais, principalmente, e do Nordeste que buscavam um pedaço de terra para viver e plantar. Esses homens e mulheres depois vieram a se autorreconhecer e ser identificados como posseiros.

Antes da chegada dos posseiros, já existia nestas áreas uma ocupação incipiente. Em 1878, instalou-se uma fábrica de tecidos em Pau Grande, área vizinha às terras palco dos conflitos que serão abordados. Inicialmente chamada de Fábrica de Tecidos Pau Grande, em 1885 ela teve seu nome alterado para Companhia de Fiação e Tecidos Pau Grande. Em 1892, passou a chamar-se Companhia América Fabril (CAF), porque a empresa passou a adquirir fábricas em outros locais do estado e, devido a isso, seu nome anterior estava em desacordo com essa expansão (WEID; BASTOS, 1986). Nos últimos anos do século XIX e durante a primeira metade do século XX, essa fábrica expandiu

5 Os entrevistados se referem às terras da gleba América Fabril também como terras da "parte do Incra", "terras da América Fabril", "do outro lado da estrada" e, algumas vezes, "Cachoeira Grande". No decreto de desapro priação, essa área foi denominada "gleba América Fabril", termo que será utilizado aqui.

6 A luta pela desapropriação nessas áreas foi conduzida concomitantemente e pelas mesmas pessoas. Por isso. optou-se por investigar ambos os casos. 
seus domínios territoriais na região e parte da terra que conquistou foi utilizada como local de moradia para os seus funcionários.

Já a Fazenda Conceição de Suruí foi ocupada pelo menos desde a primeira metade do século XX por supostos proprietários. Estes e a fábrica de tecidos foram, posteriormente, identificados pelos posseiros como grileiros.

A identificação dos sujeitos como posseiros e grileiros deve ser entendida no contexto em que essa classificação se constituiu, na e para a ação política. Com base nessa perspectiva, grileiros e posseiros devem ser considerados categorias que explicitam relações e características de um determinado grupo social em um dado contexto e não noçóes cristalizadas de forma atemporal ${ }^{7}$. Estes sujeitos foram os antagonistas nas lutas por terras que se desenvolveram na região entre as décadas de 1960 e 1970.

Em linhas gerais, os conflitos nestes locais tiveram início a partir da resistência dos posseiros diante da ameaça de despejos dos grileiros. Isso ocorreu porque a ocupação das terras por posseiros provocou a reação da CAF, que alegava ser dona da área ocupada. Processo similar se passou na Fazenda Conceição de Suruí. A fábrica e os supostos donos da Fazenda Conceição de Suruí empreenderam tentativas de despejo com a intenção de banir os novos ocupantes das terras que eles diziam ter domínio. Alguns posseiros, entretanto, recusaram-se a deixar a terra ocupada. Era o início de uma resistência que atravessaria a segunda metade da década de 1960 e a primeira de $1970^{8}$.

Os conflitos por terra gerados a partir da resistência dos posseiros às tentativas de despejo realizadas pelos grileiros não é particularidade do caso estudado. Analisando a mobilização do campesinato entre os anos 1950 e 1964 no estado do Rio de Janeiro, Grynszpan (1987) mostrou que o despejo ou simplesmente sua ameaça despertou nos lavradores uma reação de luta por suas terras. Esse autor explica que o despejo representava náo apenas uma ameaça aos lavradores, mas a todo um modo de vida e ao conjunto de relaçóes sob os quais estavam assentados, visto que

7 Na construção dessa perspectiva, as orientações de Thompson (1987) e Grynszpan (2009) foram centrais.

8 Uma explicação mais completa sobre o processo de ocupação da área em questão, os antecedentes dos con flitos e os atores em cena pode ser vista em Teixeira (2011), principalmente no capitulo um 
[...] a terra não é, para o camponês, um simples local de trabalho e de habitação, mas sim a base para a reprodução de sua condição camponesa e, consequentemente, de uma série de relações sociais, da família, de valores. Por isso, ele percebe o seu futuro como vinculado à terra, e a decisão de abandoná-la não é um mero cálculo de custos e benefícios. (GRYNSZPAN, 1987, p. 65).

Com isso, conforme concluiu Grynszpan (1987), a reação aos despejos se tornou uma alternativa dos lavradores para manterem sua condição camponesa, seu vínculo com a terra e também seu sustento e moradia. Contudo, a reação e a revolta só ocorrem na medida em que o despejo seja visto pelos lavradores como uma ação ilegítima, injusta e não inevitável, ocorrendo sob a quebra de autoridade daquele que despeja (GRYNSZPAN, 1987).

Neste artigo, será feita uma análise das formas de ação empregadas por esses posseiros para conseguir a desapropriação das terras em questão. As desapropriaçóes da gleba América Fabril e da Fazenda Conceição de Suruí ocorreram definitivamente em 1973 e 1974, respectivamente, e foram as únicas realizadas no estado do Rio de Janeiro entre o golpe de 1964 e o fim dos anos 1970 , momento apontado por grande parte da historiografia como sendo de abertura política9.

\section{Formas de ação coletiva}

\section{I O andar e a luta a partir da legislação}

As lutas dos posseiros em Magé se davam principalmente com dois fins: açóes com caráter de urgência para frear os despejos e garantir a permanência na terra e atuaçáo para conseguir a desapropriação.

A principal ação dos posseiros de Magé para conseguir a desapropriação da gleba América Fabril e Fazenda Conceição de Suruí era pressionar as autoridades. Essa ação ocorria, principalmente, através de idas dos trabalhadores, dirigentes e assessores das entidades sindicais que representavam os trabalhadores rurais aos órgãos públicos responsáveis pela questão agrária. No Rio, visitava-se

9 Até onde se pôde identificar na bibliografia, após o golpe de 1964, somente em 1981 foi feita uma nova desapropriação em terras fluminenses: o assentamento da Fazenda São josé da Boa Morte, no Município de Cachoeiras de Macacu, em 22 de janeiro. No contexto nacional, um rápido levantamento revelou que houve. ainda, um caso de desapropriação de terras nesse periodo no Ceará: Fazenda Japuara, nos sertões de Canindé (BARREIRA, 1992). 
primordialmente a sede regional do Instituto Nacional de Colonização e Reforma Agrária (Incra). Em Brasília, ia-se ao Incra nacional, ao Ministério da Agricultura e ao Ministério da Justiça, principalmente. Antonio Ernesto ${ }^{10}$ contou que, quase todo mês, esses representantes iam a Brasília para pressionar as autoridades. Já Altamir" explicou que as idas constantes dos trabalhadores aos órgãos governamentais eram importantes para manter a questão da desapropriação na ordem do dia.

Ia-se ao Incra porque era a instituição responsável desde nove de julho de 1970, data da sua criação, por promover e executar a reforma agrária no país. Ia-se, também, ao Ministério da Agricultura porque era a instituição à qual o Incra estava vinculado na época. Tratava-se, portanto, de ir a essas entidades com o objetivo de solicitar a elas a desapropriação da Fazenda Conceição de Suruí e gleba América Fabril. O Ministério da Justiça era visitado quando havia alguma questão referente à violência sofrida pelos trabalhadores.

Silveira-Lindoso (1983) chamou essa forma de ação dos trabalhadores de Magé de andar. $\mathrm{O}$ andar consistia em "[...] idas sistemáticas às autoridades para apressar o despacho do processo e exigir uma soluçáo que atendesse aos interesses dos lavradores" (SILVEIRA-LINDOSO, 1983, p. 36). A autora explica que

Andar foi a categoria mais usada para se falar de como os lavradores de Cachoeira haviam reagido às ameaças. Pode ser entendida como um sinônimo de "lutar" ou como uma forma de luta. Pode até aparecer, sem dúvida, uma forma de luta um tanto burocrática, já que o andar significa ir aos escritórios e tribunais acompanhando o processo, ir atrás dos juizes e das autoridades, "pedindo" ou "pressionando" por uma solução a favor dos lavradores em Cachoeira. Quem andava era geralmente um grupo, não todos. lam a Magé, Niterói, Guanabara, segundo a necessidade. (SILVEIRA-LINDOSO, 1983, p. 48).

Mas como se organizavam as idas dos trabalhadores aos órgãos públicos? No início da luta contra a América Fabril, ainda nos anos 1960, os trabalhadores se organizavam em pequenos grupos. $\mathrm{Na}$ época, essa organização ainda era precária, contou um dos entrevistados, pois o Sindicato dos Trabalhadores

10 Dirigente sindical. Ocupou cargos no STR de Magé ao longo dos anos 1970 e 1980 e, em alguns momentos, na Fetag-RJ. Morador da Fazenda Conceição de Suruí.

II Assessor jurídico da Fetag/RJ e do STR de Magé nos anos 1970. Posteriormente, tornou-se assessor jurídico da Contag. 
Rurais (STR) ainda não estava organizado. Com a criação do STR, este pôde contribuir para a luta travada pelos trabalhadores, que entâo se intensificou ${ }^{12}$. Neste ponto, vale destacar que a atuação do Movimento Sindical dos Trabalhadores Rurais (MSTR) na luta pela terra nesses casos foi central, como se verá ao longo desta seção ${ }^{13}$.

As inúmeras referências ao andar mencionadas nas entrevistas indicam a força dessa estratégia de atuação dos trabalhadores do campo na segunda metade dos anos 1960 e na primeira de 1970. Sobre esse aspecto, Antonio Ernesto contou:

[...] mas pra entrar, pra gente conseguir essa desapropriação aqui [Conceição de Suruí], nós recebemos uma base 12 mandados de despejo. Resistimos aos mandados de despejo. Uma hora era carta do Incra; outra hora, era ministro da reforma agrária. E a gente foi em Brasília diversas vezes, pedir a desapropriação, mas era uma época da ditadura militar. A gente sofria muita pressão. Os grileiros só alegavam que todos nós era comunista e subversivo. Coisa que nós não entendia o que era subversão, o que era comunista. Comunista, pra nós, era uma coisa comum, que serve pra todo mundo. Né? ${ }^{14}$

É possível, por meio do trecho a seguir, saber um pouco melhor como se davam as idas dos trabalhadores e dirigentes a Brasília em busca de apoio na luta pela. O seguinte diálogo revela, ainda, a constante presença do MSTR no apoio aos trabalhadores de Magé.

Antonio Ernesto: Naquela época, quase todo mês a gente tava em Brasília junto com a Contag. Na época, nós tinha uns companheiros muito bons na Contag. Lutava-se muito no Brasil inteiro pró-reforma agrária.

Marco: Na época, o senhor ia pra Brasília? Com quem?

Antonio Ernesto: la com a Contag, Fetag [Federação dos Trabalhadores na Agricultura do Estado do Rio de Janeiro]. Sindicato, representante do sindicato. A gente ia a Brasília. Lá em

12 Entrevista com Antonio, Paulinho, Jessé, José, Salvador e Sebastião concedida a Leonilde Servolo de Medeiros no dia 30/09/1982, disponivel no Núcleo de Pesquisa. Documentação e Referência sobre Movimentos Sociais e Política Públicas no Campo do programa de Pós-graduação de Ciência Sociais em Desenvolvimento, Agricultura e Sociedade da Universidade Federal Rural do Rio de Janeiro (NMSPP/CPDA/UFRRJ). As falas transcritas foram mantidas conforme a narrativa dos entrevistados.

13 A importância do MSTR para estas lutas e a sua inserção no caso pode ser mais bem entendida em Teixeira (20II).

14 Entrevista com Antonio Ernesto concedida a Marco Antonio Teixeira no dia 05/05/2010, disponivel no NMSPP/CPDA/UFRRI. 
Brasília a gente se juntava à Contag. [...] Ficava três dias pra conseguir reunião com o Incra, na Câmara de Deputados. Era uma luta braba mesmo. Primeiro, da América Fabril; depois, gleba da Fazenda de Conceição de Suruí ${ }^{15}$.

Os responsáveis por visitar os órgãos públicos eram as principais lideranças locais, dirigentes do STR de Magé, com representantes da Fetag/RJ e Contag, quando era o caso, geralmente acompanhados dos assessores jurídicos.

Se as idas a Brasília eram feitas basicamente pelos líderes da luta e dirigentes sindicais - uma vez que a longa distância implicava custos que nem sempre era possível à organização sindical financiar -, nas idas ao Rio de Janeiro, em alguns casos, os demais trabalhadores rurais participavam das mobilizaçóes. Estes iam a locais como a Câmara dos Vereadores e o Palácio Guanabara; todavia, outras circunstâncias também mobilizavam estes trabalhadores. Isso ocorria quando era preciso pressionar o juiz por algum motivo. Pressionava-se o juiz através de idas a sua casa, por exemplo, para forçá-lo a decidir favoravelmente aos trabalhadores em um processo judicial ${ }^{16}$.

Antonio Ernesto contou que eles enchiam de três a quatro ônibus nas idas ao Rio de Janeiro para protestar. É marcante, em sua fala, a referência à união dos trabalhadores como um elemento que possibilitou a realização destas açôes. Ele explicou: "Você chamava o pessoal. Nós queremos montar quatro ônibus rumo ao Incra, rumo ao governo do Estado, amanhá. 24 horas... Nós juntava”. E essa união era importante para a arrecadação de recursos que viabilizariam a viagem. A mobilização dos trabalhadores para essas ações se fazia individualmente, por meio de visita a cada pessoa e/ou da distribuição de panfletos de convocação, explicou Antonio Ernesto.

Apesar de, na entrevista, Antonio Ernesto citar alguns casos de mobilizaçáo dos trabalhadores para o andar - sobretudo quando essa ação era empreendida no próprio estado do Rio de Janeiro -, Silveira-Lindoso diz que, em geral, era somente um grupo (uma comissão) ou apenas uma pessoa que ia às autoridades pressioná-las pela desapropriação. "Fazia-se uma coleta para pagar a passagem e a estadia e um grupo ou apenas um deles andava, tentando

15 Entrevista com Antonio Ernesto e Celita concedida a Marco Antonio Teixeira no dia 21/07/20 10, disponivel no NMSPP/CPDA/UFRRJ.

16 Entrevista com Manoel Ferreira de Lima concedida a Leonilde Medeiros em 1982, disponivel no NMSPP/CPDA/ UFRRJ. 
conseguir a desapropriaçãa" (SILVEIRA-LINDOSO, 1983, p. 42); afinal, ir à cidade exigia dinheiro para passagem, alimentaçáo, hospedagem, além de representar um relativo abandono da lavoura. Em alguns casos, os trabalhadores e/ou dirigentes precisavam se preocupar, inclusive, com a roupa que usariam em uma conversa com alguma autoridade do governo. Foi o que contou Antonio Ernesto. Ele explicou que, nas reunióes com os ministros, era preciso utilizar terno e gravata, roupa que ele não tinha. Como ele não possuía recursos para comprar um terno, alguns trabalhadores se reuniram e juntaram dinheiro para lhe comprar a roupa adequada. Assim, ele pôde ir a Brasília negociar com o ministro o adiamento do despejo dos posseiros da gleba América Fabril. Antonio Ernesto contou, ainda, que foi possível também comprar os alimentos consumidos na viagem com o dinheiro reunido pelos trabalhadores ${ }^{17}$.

Em suma, os depoimentos citados revelam as estratégias criadas pelos trabalhadores para suprir a falta de recursos necessários para os deslocamentos até o Rio de Janeiro ou Brasília. Mais do que isso, mostram que havia envolvimento e aprovação dos trabalhadores com a luta, ao ajudarem com contribuiçôes financeiras para o andar. Altamir destacou que os trabalhadores da Fazenda Conceição de Suruí e gleba América Fabril estavam constantemente mobilizados e atentos para o que estava acontecendo, apoiando o encaminhamento da luta conforme era viável ${ }^{18}$. Chamar a atençáo para o envolvimento dos trabalhadores rurais da gleba América Fabril e Fazenda Conceição de Suruí com a luta pela terra, e não só das lideranças, implica destacar a importância de se considerar as pessoas comuns como sujeitos da história. Já a discussão sobre a necessidade de roupa adequada para uma reunião revela elementos presentes no cotidiano daqueles que lutam (elementos que fazem parte da preparação da ação), mostrando a necessidade de os trabalhadores se apresentarem de uma determinada forma para o interlocutor por ocasiáo de uma negociação política.

Sobre a mobilização dos trabalhadores no andar (se quem andava era um grupo numeroso ou apenas uma comissão), o que as entrevistas indicaram foi

17 Entrevista com Antonio Ernesto concedida a Marco Antonio Teixeira no dia 12/07/20 II, disponível no NMS PP/CPDA/UFRRJ.

18 Entrevista com Altamir concedida a Marco Antonio Teixeira no dia 23/06/20I I, disponível no NMSPP/CPDA/ UFRRJ. 
que, nas ações empreendidas no próprio município de Magé, com as pressões ao juiz (quando este decretava um despejo), ou mesmo nas idas ao Incra ou ao Palácio do Governo do Estado do Rio de Janeiro, buscava-se mobilizar o maior número de trabalhadores como forma de ampliar a ação e causar um maior impacto. As idas a Brasília, entretanto, por exigirem mais tempo e recursos, eram empreendidas por um grupo restrito de pessoas, normalmente lideranças locais, do STR, e dirigentes da federação, além dos seus assessores, como advogados, acompanhados por representantes da Contag. Como uma das lideranças do sindicato era Antonio Ernesto, e ele era posseiro em CS, isso garantia que ele tivesse um duplo papel: dirigente e morador da área.

Deve-se entender o andar a partir da lógica de ação do MSTR no referido momento histórico, de agir tendo por base a legislação. Altamir explicou que essa atuação era o que permitiam as circunstâncias naquele período de ditadura civil-militar, quando a ação de trabalhadores organizados era reprimida pelo governo.

A orientação de agir com base na lei está presente também na fala de Acácio $^{19}$. Ele explicou que, após 1964, não havia condições de resistência direta. Assim, a única forma de conter os despejos era por meio da justiça. Ele falou: "Chegamos a ter dez advogados trabalhando direto, defendendo daqui, defendendo dali. Conflito mesmo, de resistência, náo houve"20. Depois do golpe, o trabalho da federação junto ao sindicato era primordialmente de defesa jurídica. "O trabalhador que se sentia molestado em seus direitos, vinha e colocava e a gente ia fazer a defesa dele na justiça”, explicou Acácio ${ }^{21}$.

Para trabalhar com base na legislação, ou seja, recorrendo-se a açóes na justiça, foi fundamental a presença dos advogados nos sindicatos e na federação. Segundo Altamir, a atuação, por intermédio dos mecanismos legais, foi uma orientação incentivada pela Contag depois que José Francisco da Silva assumiu a presidência da confederação em $1968^{22}$.

9 Dirigente sindical. Ocupou cargos na diretoria da Fetag/RJ no pós-1964 e na diretoria da Contag após 1971. 20 Entrevista com Acácio concedida a Leonilde Medeiros no dia 26/10/1982, disponivel no NMSPP/CPDA/UFRRI. 21 Entrevista com Acácio concedida a Leonilde Medeiros no dia 26/10/1982, disponivel no NMSPP/CPDA/UFRRJ.

22 Entrevista com Altamir concedida a Marco Antonio Teixeira no dia 23/06/20I I, disponivel no NMSPP/CPDA/ UFRRJ. 
Como o sindicato de Magé não tinha condições financeiras de pagar o salário de um advogado, a federação enviava um dos seus estagiários ao STR para prestar assessoria jurídica. O advogado que trabalhava em Magé ia ao STR duas vezes por semana, ocasiôes em que ele atendia os trabalhadores rurais que buscavam orientação e fazia o encaminhamento de atividades junto com os dirigentes - colhia informaçóes sobre o andamento dos conflitos, preparava ofícios e cartas, entre outras atividades. $\mathrm{O}$ advogado tinha, ainda, que acompanhar os processos na justiça e estar presente nas audiências que envolviam algum trabalhador rural ou o sindicato $^{23}$.

Além disso, os assessores jurídicos colaboravam na orientação dos trabalhadores sobre como proceder na relação com os grileiros. Isso era importante para evitar que algum trabalhador rural fosse enganado por aqueles que reclamavam a propriedade da terra. Os advogados orientavam os trabalhadores a náo ceder, a não fazer acordo, nem assinar nenhum papel a pedido dos grileiros. Antonio Ernesto explicou que esse trabalho era importante para conscientizar os trabalhadores sobre como agir com o grileiro.

Sendo assim, trabalhadores rurais, dirigentes sindicais e assessores jurídicos buscavam fazer valer seus direitos e reivindicaçôes pelo pedido do cumprimento das leis. Nesta perspectiva, o Estatuto da Terra ${ }^{24}$ (BRASIL, 1964) e o Estatuto do Trabalhador Rural ${ }^{25}$ (BRASIL, 1963) foram importantes instrumentos de luta. Altamir explicou que o Estatuto da Terra era uma legislação ambígua e ele buscava se aproveitar das brechas presentes na lei para tentar convencer as autoridades a atenderem aos pedidos dos trabalhadores rurais.

Palmeira (2009) já havia chamado a atenção para o fato de que no pós-golpe a legislação havia se transformado em uma importante ferramenta de luta para os trabalhadores. A partir de estudo sobre a ocorrência de conflitos na Zona da Mata de Pernambuco em um momento de desmobilizaçáo política (1964-1974), o autor identificou que o Estatuto do Trabalhador Rural se transformou em uma importante ferramenta de luta para os trabalhadores, visto que, quase diariamente, eles se mobilizavam politicamente para obrigarem

23 Entrevista com Antonio Ernesto e Celita concedida a Marco Antonio Teixeira no dia 2 I/07/20 I 0, disponível no NMSPP/CPDA/UFRRJ.

24 Lei n ${ }^{\circ} 4.504$, de 30 de novembro de 1964 (brasil, 1964).

25 Lei no 4.214, de 02 de março de 1963 (brasil, 1963). 
os proprietários a atenderem às disposições da lei. Para Palmeira (2009, p. 194), no contexto pós-golpe de 1964, “[...] a simples luta pelo cumprimento da legislação assume muitas vezes uma feição radical insuspeitada, podendo pôr em xeque a própria continuidade das relaçóes sociais na agroindústria".

No caso estudado por Palmeira (2009), ou ainda na situação tratada aqui, um pesquisador que, durante seu trabalho, procurasse por formas convencionais de ação coletiva (como greves e açôes armadas), provavelmente, teria dificuldade em encontrá-las e poderia chegar à conclusão equivocada de ausência de lutas sociais.

Neste trabalho, a perspectiva de análise se voltou para as identificar formas de açáo coletiva dos trabalhadores rurais da gleba América Fabril e Fazenda Conceiçáo de Suruí de modo a perceber se alguma delas representava um ato de resistência às tentativas de despejo que eles vinham sofrendo e/ou ação na busca pela desapropriação. A luta com base na legislação expressa essa forma alternativa de ação coletiva, que deve ser entendida no contexto em que ela foi realizada.

O que se pôde interpretar - a partir dos dados apresentados e com base na noção de açáo coletiva que se elaborou a partir do diálogo com a literatura -, foi que a forma de açáo do grupo de trabalhadores rurais analisado efetivou-se, principalmente, a partir do andar e da luta com base na legislação. Por isso, não faz sentido referir-se simplesmente à desmobilizaçáo nas lutas no campo no período da ditadura civil-militar, mas sim a uma reorientação da ação, organizada com base no novo contexto e nos limites que o período colocava ou, para usar um termo de Elias, na figuração dada no caso estudado.

Em suma, a opção pela negociação e resolução dos problemas pelas vias legais, como o recurso ao Judiciário ou a denúncia de despejos e violências sofridas a órgãos governamentais, que se expressava no andar, representou uma forma de encaminhar as lutas dos trabalhadores rurais. Neste contexto, privilegiava-se a luta por vias legais e não mais o enfrentamento direto, com ações de resistência armada ou ocupaçóes, como ocorreu em alguns locais nos primeiros anos da década de 1960.

\subsection{O envio de ofícios}

O andar era complementado por outra ação: o envio de ofícios a autoridades do Estado. A intenção dessa prática era fazer com que os conflitos na 
Fazenda Conceição de Suruí e na gleba América Fabril fossem constantemente lembrados nos escritórios das entidades responsáveis pelo encaminhamento da questão agrária e assim permanecessem na agenda política como uma pauta pendente. Além disso, segundo Antonio Ernesto, os ofícios tinham a função de ser um registro escrito das reivindicaçóes feitas pelos trabalhadores e dirigentes sindicais no andar: "Se você pede de boca, é igual ao vento, [...] fica no ar [...]. Tinha que mandar por escrito pra cobrar"26.

Os ofícios eram enviados principalmente para as mesmas instituiçóes visitadas no andar: Incra regional, Incra nacional, Ministério da Agricultura e Ministério da Justiça. Em geral, os ofícios obedeciam à hierarquia sindical antes de serem encaminhadas aos órgãos públicos competentes, ou seja, primeiramente, eram enviados do STR para a Fetag/RJ, e desta para a Contag; então, eram encaminhados para as autoridades às quais se destinavam. Contudo, isso nem sempre foi regra. Houve casos em que a comunicação via ofício se fazia de forma direta entre STR e Contag, sem a intermediaçáo da federação.

Os documentos enviados pelo sindicato e federação à Contag geralmente solicitavam que a Confederação interferisse junto ao Incra no sentido de avançar na luta pela desapropriação da área em questáo (gleba América Fabril e Fazenda Conceição de Suruí). Pediam, também, que a Contag acompanhasse o andamento do processo de desapropriaçáo em Brasília, junto ao Incra e ao Ministério da Agricultura. Na maioria das vezes, junto a essas solicitações, pedia-se urgência na ação, uma vez que os trabalhadores estavam sob ameaça de despejo.

Deve-se destacar que a Contag teve um papel fundamental nessa luta, uma vez que coube a ela ser a interlocutora com as autoridades para pressioná-las e cobrar soluçóes para o caso em contenda. Era a Contag que estava em Brasília e podia acompanhar, de forma mais próxima, o andamento do processo de desapropriação. Mas a Confederação só tinha conhecimento dos conflitos em Magé por meio da Fetag-RJ e do STR de Magé. Foi o trabalho dessas entidades que davam sustentaçáo à atuaçáo da Confederaçáo em Brasília junto às autoridades. Cabia, portanto, primeiro ao STR, normalmente, relatar a situação dos trabalhadores rurais e apontar suas reivindicaçóes.

26 Entrevista com Antonio Ernesto concedida a Marco Antonio Teixeira no dia 12/07/2011, disponivel no NMS PP/CPDA/UFRR/ 
Os ofícios da Contag para a Fetag e, em alguns casos, para o STR de Magé, eram para prestar esclarecimentos sobre as açôes da confederação junto às autoridades no tocante ao processo de pressão para obter a desapropriação e para informar sobre o andamento do processo desapropriatório no Incra e no Ministério da Agricultura. Também solicitavam informações, quando necessário. Medeiros (1983) também identificou esta situação:

[...] os Sindicatos encaminhavam a denúncia dos conflitos à Fetag, muitas vezes acompanhadas de relatórios mais pormenorizados; esta, por sua vez, os levava à Contag que funcionava como porta voz do movimento sindical nas instâncias federais de poder. (MEDEIROS, 1983, p. 30).

Sobre a elaboração dos ofícios, Altamir contou que se reunia com os dirigentes do sindicato e estes passavam para ele a situação do conflito. Depois disso, ele redigia o documento e encaminhava inúmeras cópias para diversos órgãos, o que, segundo Antonio Ernesto, era uma forma de notificar, por exemplo, o Ministério da Agricultura sobre os pedidos que eram feitos ao Incra. Assim, caso quisesse, o Ministério poderia acompanhar a questão e forçar o Incra a resolvê-la, uma vez que esta autarquia lhe era subordinada. Os ofícios do sindicato, quando eram enviados diretamente para os órgãos do governo, iam também com cópia para a Contag e a Fetag para fazer com que essas instituiçóes tomassem conhecimento da situação e pudessem acompanhar e cobrar o andamento dos pedidos. O objetivo era "se cercar por todos os latos", explicou Antonio Ernesto. Ele contou que, muitas vezes, os ofícios geravam algum tipo de resultado. Contudo, quando passava um mês e nada acontecia, eles mandavam outro ofício ${ }^{27}$.

Nos ofícios, as entidades sindicais descreviam a situação conflitiva em curso na gleba América Fabril e Fazenda Conceição de Suruí e solicitavam providências junto às esferas federais no sentido de solucionar os litígios por terra. A principal reivindicaçáo presente era o pedido de desapropriaçáo das terras, vista como a única solução definitiva para as disputas envolvendo ambas as glebas. Houve, também, um número significativo de ofícios solicitando intervenção das autoridades na contenção do despejo.

27 Entrevista com Antonio Ernesto concedida a Marco Antonio Teixeira no dia 12/07/2011, disponivel no NMS PP/CPDA/UFRRI. 
$\mathrm{Na}$ descrição sobre os conflitos, as entidades sindicais buscavam construir uma imagem de Magé como uma área de "tensão social" em virtude dos conflitos fundiários. Geralmente, esse era o ponto de partida para a sequência do relato, que descrevia os problemas vividos pelos trabalhadores rurais de um determinado local.

Em um ofício enviado pela Fetag/RJ à Contag em fevereiro de 1973, há um anexo que seria a cópia de algumas notas encaminhadas aos jornais sobre os acontecimentos envolvendo as disputas por terra em Magé. No documento, foi dito: "O clima é de insegurança e tensão social, estando, inclusive o próprio Presidente do Sindicato entre aqueles ameaçados de despejo" 28 . Dito isso, solicitam à Contag que não só divulgue o problema mas também interceda junto às autoridades governamentais para que ocorra um "[...] breve desfecho dessa angustiante situação, trazendo a tranquilidade ao $\mathrm{Mu}$ nicípio de Magé" 29 .

Caracterizar a situação em Magé como de "tensão social" era uma estratégia da entidade sindical para enquadrar este caso em uma situação prevista no art. 15 do Estatuto da Terra (BRASIL, 1964) como prioritária para fins de reforma agrária. O texto do referido artigo diz: "A implantação da Reforma Agrária em terras particulares será feita em caráter prioritário, quando se tratar de zonas críticas ou de tensão social" ${ }^{30}$. Isso mostra a articulação das estratégias de açáo no encaminhamento da luta pela desapropriação de terras: o envio de ofícios e a luta com base na legislação ocorriam de forma concomitante e se complementavam.

Além do termo "tensão social", falava-se em "desespero", "angústia", "intranquilidade", sensaçôes provocadas pela constante ameaça de despejo a que estavam submetidos os trabalhadores rurais. $\mathrm{O}$ despejo chegou a ser retratado em um dos documentos como um "fantasma" na vida dos trabalhadores e suas famílias ${ }^{31}$. A noção de "tensão" e os outros qualificativos eram normalmente contrapostas à de "paz" e "tranquilidade", sensaçóes que só seriam alcançadas com a resolução dos conflitos. "Tensáo social", desta forma, sintetizava a

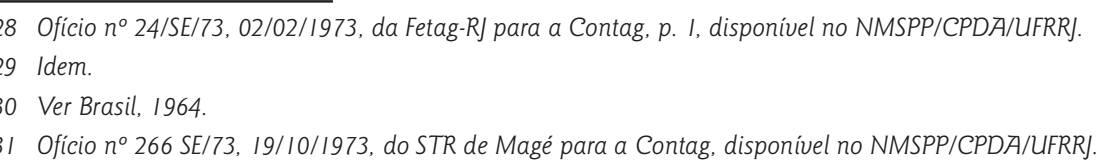


situação deflagrada de conflitos de terras entre posseiros e grileiros e servia para se referir tanto a um ato de despejo em si, como a sua ameaça ou a algum outro temor dos trabalhadores e suas famílias.

Esse caso que ocorreu em Magé demonstra que se recorria a aspectos subjetivos, que faziam parte da situação, para elaborar a apresentação do problema. Relatar a condição em que viviam era uma forma de apresentar às autoridades do governo a gravidade da situaçáo dos trabalhadores rurais e justificar a urgência para que a desapropriação ocorresse. Buscava-se, com isso, sensibilizar os representantes do Estado para a urgência de intervirem em favor dos trabalhadores.

Em alguns casos, os relatos sobre as condições dos trabalhadores rurais eram enviados também à imprensa. A tentativa de divulgar na imprensa os acontecimentos ocorridos em Magé revela o esforço do MSTR de publicizar esses episódios e, assim, divulgar a "angústia" que vinham passando os trabalhadores. Segundo Altamir, as notícias que eram divulgadas na imprensa ajudavam a manter a questáo na ordem do dia e a divulgar a situação em Magé.

As notas à imprensa que foram localizadas acompanhavam o ofício $n^{\circ} 24 / \mathrm{SE} / 73^{32}$ e estavam em papel datilografado. Por isso, não é possível saber se elas foram publicadas. Todavia, sua existência pelo menos revela uma tentativa dos trabalhadores de tornarem os acontecimentos de conhecimento público, como se quer frisar aqui.

Em linhas gerais, é possível identificar nesses ofícios os argumentos utilizados pelas entidades sindicais para convencer as autoridades a realizarem a desapropriação das terras. Um documento produzido pela Fetag/RJ e enviado à Confederação é indicativo do teor constante nessas correspondências. Este documento se destaca entre os demais, pois nele se encontra grande parte da argumentação utilizada pelo movimento sindical em outras correspondências ao longo do conflito pela desapropriação da gleba América Fabril e da Fazenda Conceição de Suruí. Como explicou Altamir, em geral, um documento era produzido e, a partir dele, produziam-se outros semelhantes, ou mesmo iguais, para serem enviados a diversos órgãos. Isso ajuda a explicar a repetição da argumentação em diversos documentos.

32 Oficio n 24/SE/73, 02/02/1973, da Fetag-RJ para a Contag, p. I, disponivel no NMSPP/CPDA/UFRRJ 
O documento mencionado anteriormente é um memorial de maio de 1971, encaminhado pela Fetag/RJ à Contag, contendo uma descrição dos problemas que afligiam os trabalhadores rurais do estado do Rio de Janeiro, particularmente os de Magé. ${ }^{33}$ Relatos como esse eram comuns também para outros casos de conflitos por terra. Destinado genericamente "às autoridades", através desse memorial, a Fetag/RJ informava à Contag a situação dos trabalhadores rurais em Magé e solicitava à Confederação que interviesse junto às autoridades, pressionando-as a agir em prol dos trabalhadores ${ }^{34}$. Dias depois, a Contag acusou o recebimento do memorial e disse ter tomado as providências possíveis, encaminhando às autoridades competentes o memorial ${ }^{35}$.

O memorial buscou chamar a atenção da opinião pública e das autoridades para a situação dos camponeses residentes no município de Magé que estavam sendo alvo de despejo das terras que ocupavam. Neste memorial, foram tratados mais especificamente os casos da Fazenda Rio D'Ouro - Cachoeiras ${ }^{36}$.

No memorial, a Fetag/RJ afirmava que, mesmo sabendo do risco permanente, os camponeses não pararam de trabalhar, produzindo o máximo rendimento, retirando daquele solo seu sustento e alimentando grande parte da população do grande Rio. Há, nessas palavras, uma concepção de que o trabalho do camponês beneficia não só a população do campo mas também a da cidade, na medida em que fornece alimentos para o consumo no meio urbano. Esse argumento está presente em vários outros documentos e na fala de alguns entrevistados e parecia ser utilizado como forma de justificar e legitimar a relevância do trabalho do homem do campo. Com isso, ressaltava-se a necessidade de o trabalhador rural ter acesso à terra, condição para continuar produzindo. Com esse argumento, portanto, buscava-se construir uma imagem que destacava o papel social do homem do campo. Altamir explicou que esse argumento era utilizado para mostrar que, caso os camponeses não

33 "Memorial sobre problemas dos Trabalhadores rurais do Estado do Rio de Janeiro", de maio de 197I. O documento consta no anexo do Ofício No 180/DA/7I, de 06/05/I97I, da Fetag-RI para a Contag, disponivel no NMSPP/CPDA/UFRRJ.

34 Ofício No 180/DA/7I, de 06/05/I97I, da Fetag-RJ para a Contag, disponivel no NMSPP/CPDA/UFRRJ.

35 Ofício No SE/597/7I, de 18/05/I97I, da Fetag-RJ para a Contag, disponivel no NMSPP/CPDA/UFRRJ.

36 Como Antonio Ernesto explicou, em uma entrevista. (concedida a Marco Antonio Teixeira no dia 12/07/201 I. disponivel no NMSPP/CPDA/UFRRJ) que esta área é a que os posseiros chamavam de gleba América Fabril. 
pudessem produzir, o abastecimento da cidade seria prejudicado, afetando toda a população da cidade.

A Fetag/RJ argumentava, ainda, no memorial que, caso a desapropriação não ocorresse e as terras onde eles viviam fossem transformadas em lotes urbanos, o "cinturão verde" e as reservas florestais que estavam no entorno da cidade do Rio de Janeiro seriam destruídos. Além disso, o memorial sugeria que a expulsão das famílias de posseiros das terras em que viviam poderia provocar o aumento da mendicância, prostituição e delinquência. Com tudo isso, o que se pode perceber é que há uma estratégia argumentativa no memorial a fim de ampliar o problema do universo rural para o universo urbano. Tratava-se de tornar o despejo dos trabalhadores rurais não apenas um problema restrito ao local onde ele ocorria mas também uma problemática social mais ampla.

No memorial, para embasar seu pedido de desapropriação de terras, a Fetag/RJ recorreu até ao discurso de uma autoridade eclesiástica para mostrar o apoio que a questão da reforma agrária recebia no momento. Tratava-se da fala do Papa Paulo VI, de 1966, na Conferência Mundial da Reforma Agrária, promovida pela Organizaçáo das Naçóes Unidas para Agricultura e Alimentação (FAO), no qual ele considera a reforma agrária necessária para aumentar a renda, melhorar as condiçóes e a segurança do emprego, estimular a iniciativa, redistribuir a terra entre os homens e torná-la produtiva, além de erradicar a pobreza e a fome. Ainda no memorial, a Federação relata outras situaçóes que caracterizam o que eles chamam de o "quadro desolador do meio rural":

a) diversas irregularidades nos Cartórios, onde políticos e figurões ditam regras e recebem favores ilícitos; b) existência de grande número de famílias que trabalham a terra sem qualquer forma de participação, no que se refere à posse; c) escrituras outorgadas sem observância às determinações legais; d) registro de escritura sem o necessário exame; e) loteamentos fantasmas, com lotes vendidos irregularmente e situação de posse duvidosa; f) 500 anos de latifúndio e consequente exploração do camponês ${ }^{37}$.

As situaçóes relacionadas têm em comum a ênfase no descumprimento da lei. Diante desse quadro, a desapropriação era vista como a única maneira

37 "Memorial sobre problemas dos Trabalhadores rurais do Estado do Rio de Janeiro", de maio de 197I. O documento consta no anexo do Ofício No 180/DA/7I, de 06/05/I97I, da Fetag-RJ para a Contag, disponivel no NMSPP/CPDA/UFRRJ. 
de sustar o despejo das famílias em Magé, bem como frear a tensão social no campo.

Além da desapropriação das terras, a Fetag/RJ apresentou outras sugestōes para a resolução dos problemas levantados: "Outra modalidade que poderia ser utilizada em curto prazo, seria a suspensão por 10 anos de quaisquer atos destinados a desalojar camponeses de suas terras: despejos, imissóes de posse, manutençóes, reintegraçóes etc.” Tentava-se, com esse pedido, uma solução temporária para o problema que só seria resolvido definitivamente mediante a desapropriação.

Por fim, no memorial, a Fetag/RJ relata já ter enviado mensagem para o Governador do Estado alertando sobre a situação de iminente despejo dos posseiros da gleba América Fabril e destaca que esse fato merece atenção das autoridades do país, pois sua não resolução será "uma autêntica vergonha nacional". Lembra, ainda, que o Estado do Rio de Janeiro se encontra na área de zona prioritária para a reforma agrária, e que, apesar disso, nada de concreto foi feito que evidenciasse essa prioridade, com exceçáo da tentativa em curso no momento em Vargem Grande, no município de Itaboraí.

Por fim, a Fetag/RJ conclui argumentando que considera essencial a dinamização das leis - Estatuto da Terra e Estatuto do Trabalhador Rural - a fim de modificar a estrutura agrária atual. Como foi dito antes, era por meio da legislação existente que o movimento sindical dos trabalhadores rurais recorria às autoridades para solicitar intervenção no caso e realizar a desapropriação.

O caso relatado serve para entender uma das formas que a luta pela terra se desenvolveu após o golpe de 1964: recurso às autoridades solicitando intervenção em prol dos trabalhadores e apoio para conter os despejos e conseguir a desapropriaçáo. Ademais, esse documento expóe os argumentos utilizados pelo MSTR para justificar e embasar seus pedidos às autoridades. Mais do que se referir a um caso, a partir desse memorial é possível entender a argumentação do MSTR junto às autoridades e a sua forma de atuar neste momento.

\subsection{Reuniões}

As açóes do MSTR no encaminhamento das lutas eram geralmente precedidas de reunióes, que tinham por objetivo socializar informaçóes, planejar atividades e mobilizar trabalhadores. Em Magé, o principal articulador das 
reuniôes na Fazenda Conceição de Suruí e gleba América Fabril foi o STR. As reuniôes, em geral, aconteciam entre dirigentes e/ou assessores do sindicato com os posseiros de cada uma dessas glebas, e entre estes e a federação. Também ocorriam reunióes entre os sujeitos que formavam cada um destes grupos: posseiros e sindicatos.

Um lavrador explicou que havia reunióes entre os trabalhadores e destes com pessoas ligadas ao movimento sindical, como advogados e dirigentes da Fetag/RJ ${ }^{38}$. Jair ${ }^{39}$ conta, por exemplo, que Acácio, dirigente da Fetag/RJ, foi por algumas vezes a Magé reunir-se com aqueles trabalhadores e apoiá-los na luta que travavam. Ele contou que os próprios trabalhadores de Magé se reuniam e juntavam dinheiro para levá-lo até lá ${ }^{40}$.

Como era um momento em que mobilizaçóes políticas eram reprimidas - ditadura civil-militar - foi preciso ter cuidado nas ocasióes de reunióes. As assembleias sindicais, para ocorrer, precisavam ser notificadas com 15 dias de antecedência ao delegado do Ministério do Trabalho, segundo alguns entrevistados. A análise do livro de atas das assembleias do sindicato revelou que após 1968, quando aparentemente o sindicato reabriu depois do golpe e voltou para cumprir suas atividades cotidianas, e ao longo de todo o ano 1970, ocorreram, em geral, assembleias gerais ordinárias e assembleias gerais extraordinárias. Antonio Ernesto explicou que as primeiras deveriam ocorrer obrigatoriamente, conforme orientação do Mistério do Trabalho. Já as segundas, ocorriam eventualmente conforme a necessidade local. Antonio Ernesto falou, ainda, que ocorreram assembleias eleitorais, embora as atas destas náo tenham sido localizadas.

As assembleias ordinárias aconteceram quase anualmente ${ }^{41}$. Nelas, discutia-se e se aprovava o relatório de atividades do sindicato (sempre em relação ao ano anterior de realização da assembleia), era feito o balanço financeiro

38 Entrevista com Antonio, Paulinho, Jessé, José, Salvador e Sebastião concedida a Leonilde Servolo de Medeiros no dia 30/09//982, disponivel no NMSPP/CPDA/UFRRJ.

39 Morador da gleba América Fabril.

40 Entrevista com Antonio, Paulinho, Jessé, José, Salvador e Sebastião concedida a Leonilde Servolo de Medeiros no dia 30/09/1982, disponível no NMSPP/CPDA/UFRRJ.

41 Após a reabertura do sindicato e até o fim de 1979, foram realizadas assembleias ordinárias nos dias II/05/1969, 10/07/1969, 27/06/1970, 29/06/197I, 21/04/1972, 01/09/1973, 22/06/1974, 05/06/1975, 21/06/1976, 04/06/1977, 26/06/1979. 
do ano anterior da data de realização da assembleia (prestação de contas) e se planejava a previsão orçamentária para o ano seguinte.

Já em relação às assembleias extraordinárias, há o registro de apenas duas no pós-golpe e até o fim de 1979. No período, ocorreu uma reunião extraordinária da diretoria e do conselho fiscal do STR de Magé, em 13 de janeiro de 1972, quando se debateu sobre o desentendimento entre o então presidente e tesoureiro do sindicato, e uma reunião ordinária da diretoria do STR de Magé, em primeiro de julho de 1972. Na ocasião, discutiu-se sobre a aprovação de gratificação aos membros da diretoria e sobre o estabelecimento de um valor a ser cobrado para a admissão de novos associados. Uma assembleia extraordinária ocorreu no dia primeiro de maio de 1979, na qual se falou sobre a aquisição de uma sede para o sindicato, e outra em 13 de dezembro de 1979, quando se discutiu sobre o aumento da mensalidade do sindicato.

Deste modo, as atas revelam que as assembleias sindicais não pareciam ser momentos de discussáo política e encaminhamento da luta pelos trabalhadores rurais. Caso isso tenha ocorrido, não houve o registro dessas discussóes. Antonio Ernesto explicou que não era possível se discutir encaminhamentos políticos e temas concernentes à luta pela terra nas assembleias, pois nelas sempre estavam presentes representantes do governo.

O tema das lutas era discutido apenas em reuniôes com um grupo restrito de pessoas e nada era registrado em papel. Os trabalhadores rurais, dirigentes e assessores encontraram, portanto, outros meios de se reunir além dos espaços formais de discussão do sindicato. Essas reuniôes tinham o objetivo de mobilizar trabalhadores, falar sobre a luta pela terra ou traçar estratégias de açóes; por isso, precisavam ocorrer sem a presença de representantes de governo. As reunióes costumavam acontecer em locais discretos e variados, para se evitar que fossem descobertas.

Antonio Ernesto falou que as reuniōes aconteciam nas próprias regiōes onde estava instalado um conflito. Assim, uma reunião sobre Conceição de Suruí ocorria em algum local da fazenda, sempre em lugares variados: no pé de um morro, embaixo de uma árvore ou na casa de alguém, como lembrou um dos entrevistados. Um dos lugares onde os trabalhadores rurais das glebas 
América Fabril e Fazenda Conceição de Suruí se reuniam era no bar da Celi$\mathrm{ta}^{42}$, localizado na beira da ponte do rio Cachoeira Grande. Celita contou que, enquanto a reuniáo ocorria, ela ficava vigiando ao redor do bar para observar se não chegaria nenhum estranho ou alguém da polícia, o que nunca ocorreu, já que o seu bar não ficava na estrada principal e a polícia só passava por lá eventualmente ${ }^{43}$. Quando trabalhadores e dirigentes desconfiavam que existiam pessoas infiltradas na reunião os vigiando, os assuntos que não podiam ser tratados na presença desses sujeitos eram omitidos.

Outro tipo de reunião também acontecia em Magé: conforme apontou Antonio Ernesto, eram reunióes para traçar estratégias de luta. Essas reuniōes eram restritas aos líderes sindicais e ao corpo de funcionários das organizaçóes sindicais. Os encontros para traçar estratégias eram importantes para que, quando eles chegassem às reunióes com os trabalhadores rurais, pudessem explicar qual era a estratégia de ação desenhada.

A ocorrência de reunióes para mobilizar os trabalhadores, traçar estratégias, socializar informaçôes indica que houve uma participação dos trabalhadores da gleba América Fabril e Fazenda Conceição de Suruí na luta pela desapropriação destas glebas para além do esperar, como apontou Silveira-Lindoso. Essas açóes mostram que a luta era vivida localmente pelos trabalhadores rurais e as reunióes eram parte importante do processo de desenvolvimento das ações coletivas empregadas.

\section{Considerações finais}

Os casos das desapropriaçóes de terras da gleba América Fabril e Fazenda Conceição de Suruí são exemplos excepcionais da resistência de um grupo de trabalhadores rurais que lutaram no contexto da ditadura civil-militar para permanecer na terra em que viviam. A particularidade da luta dos posseiros da gleba América Fabril e Fazenda Conceição de Suruí reside em seu sucesso, a desapropriação, ter sido obtido na década de 1970 , momento indicado pela bibliografia como de refluxo nas lutas no campo no Brasil devido ao contexto político.

42 Moradora da Fazenda Conceição de Suruí. Nascida em Campos dos Goytacazes, mudou-se para Magé no início dos anos 1970. Tinha um bar na área vizinha à gleba América Fabril.

43 Entrevista com Pelé, Antonio Ernesto e Celita concedida a Marco Antonio Teixeira no dia 29/07/20 10, disponivel no NMSPP/CPDA/UFRRJ. 
Neste artigo, buscou-se dar destaque às formas de ação dos trabalhadores rurais que lutaram pela permanência na terra. Para isso, foi fundamental a orientação de Thompson (1998) sobre as formas alternativas de luta. Com isso, pôde-se perceber que a luta na gleba América Fabril e na Fazenda Conceição de Suruí se efetivou basicamente por meio do recurso à legislação. Ao mesmo tempo, o andar e o envio de ofícios foram formas de manter a questáo da desapropriação na pauta do dia - sendo constantemente lembradas pelas autoridades governamentais responsáveis pela questão agrária -, e também serviam como forma de pressão sobre as autoridades para o cumprimento da desapropriação. Já as reunióes precisavam ser feitas em locais sigilosos e longe do olhar da polícia e do exército, e serviam para manter a mobilizaçáo e a participação dos trabalhadores rurais em torno da luta pela terra.

A reflexão iniciada aqui e a conjugaçáo deste com outros trabalhos poderão ajudar na compreensão das formas de ação coletiva empregadas pelos trabalhadores rurais em situaçóes de conflitos por terra no contexto de ditadura civil-militar.

Este trabalho busca, portanto, destacar a importância de uma compreensão de ação coletiva que permita identificar as maneiras variadas pelas quais os trabalhadores (mas também outros grupos sociais) podem atuar coletivamente, considerando que a figuração na qual essa atuação se desenvolve é central para a conformação da forma pela qual a açáo coletiva assume.

\section{Referências}

BARREIRA, C. Trilhas e atalhos do poder: conflitos sociais no sertáo. Rio de Janeiro: Rio Fundo, 1992.

BRASIL. Lei no 4.214, de 02 de março de 1963. Dispóe sobre o Estatuto do Trabalhador Rural. Diário Oficial da Uniáo, Brasília, DF, 02 mar. 1963. Disponível em <http://www.planalto.gov.br/ ccivil_03/leis/L4504.htm>. Acesso em: 29 set. 2015.

BRASIL. Lei no 4.504, de 30 de novembro de 1964. Dispóe sobre o Estatuto da Terra, e dá outras providências. Diário Oficial da Uniáo, Brasília, DF, 30 nov. 1964. Disponível em <http://www. planalto.gov.br/ccivil_03/leis/L4504.htm>. Acesso em: 9 ago. 2011.

CARNEIRO, A.; CIOCCARI, M. Retrato da repressáo política no campo - Brasil 1962-1985

- Camponeses torturados, mortos e desaparecidos. Brasília: MDA, 2010. 
COMERFORD, J. C. Fazendo a luta: sociabilidade, falas e rituais na construção de organizaçôes camponesas. Rio de Janeiro: Relume Dumará - Núcleo de Antropologia da Política, 1999.

ELIAS, N. Sociedade dos Indivíduos. Rio de Janeiro: Jorge Zahar Ed., 1994.

Mozart, sociologia de um gênio. Rio de Janeiro: Jorge Zahar Ed., 1995.

Escritos e ensaios 1: Estado, processo, opiniāo pública. Rio de Janeiro: Jorge Zahar Ed., 2006.

Introduçáo à Sociologia. Lisboa: Ediçôes 70, 2008.

Entrevista com Manoel Ferreira de Lima concedida a Leonilde Medeiros em 1982, disponível no NMSPP/CPDA/UFRRJ.

Entrevista com Antonio, Paulinho, Jessé, José, Salvador e Sebastiấo concedida a Leonilde Servolo de Medeiros no dia 30/09/1982, disponível no NMSPP/CPDA/UFRRJ.

Entrevista com Acácio concedida a Leonilde Medeiros no dia 26/10/1982, disponível no NMSPP/ CPDA/UFRRJ.

Entrevista com Antonio Ernesto concedida a Marco Antonio Teixeira no dia 05/05/2010, disponível no NMSPP/CPDA/UFRRJ.

Entrevista com Antonio Ernesto e Celita concedida a Marco Antonio Teixeira no dia 21/07/2010, disponível no NMSPP/CPDA/UFRRJ.

Entrevista com Pelé, Antonio Ernesto e Celita concedida a Marco Antonio Teixeira no dia 29/07/2010, disponível no NMSPP/CPDA/UFRRJ.

Entrevista com Altamir concedida a Marco Antonio Teixeira no dia 23/06/2011, disponível no NMSPP/CPDA/UFRRJ.

Entrevista com Antonio Ernesto concedida a Marco Antonio Teixeira no dia 12/07/2011, disponível no NMSPP/CPDA/UFRRJ.

FETAG-RJ. Ofício no 24/SE/73, 02/02/1973, da Fetag-RJ para a Contag, p. 1, disponível no NMSPP/CPDA/UFRRJ.

FETAG-RJ. Ofício no 180/DA/71, de 06/05/1971, da Fetag-RJ para a Contag, disponível no NMSPP/CPDA/UFRRJ.

FETAG-RJ. “Memorial sobre problemas dos Trabalhadores rurais do Estado do Rio de Janeiro", de maio de 1971. O documento consta no anexo do Ofício No 180/DA/71, de 06/05/1971, da FetagRJ para a Contag, disponível no NMSPP/CPDA/UFRRJ. 
Formas de ação coletiva: reflexões a partir dosconflitos por terra em Magé, RJ | Marco Antonio Teixeira

FETAG-RJ. Ofício no 266 SE/73, 19/10/1973, do STR de Magé para a Contag, disponível no NMSPP/CPDA/UFRRJ.

FETAG-RJ. Ofício no SE/597/71, de 18/05/1971, da Fetag-RJ para a Contag, disponível no NMSPP/CPDA/UFRRJ.

GRYNSZPAN, M. Ação política e atores sociais: posseiros, grileiros e a luta pela terra na Baixada Fluminense. FERNANDES, B. M.; MEDEIROS, L. S. de; PAUlilO, M. I. (Org.). Lutas camponesas contemporâneas: condições dilemas e conquistas - o Campesinato como sujeito político (1950 a 1980). São Paulo: UNESP, 2009. v.1. p. 35-56.

Mobilizaçáo camponesa e competiçáo política no estado do Rio de Janeiro: (19501964). 1987. 392 f. Dissertação (Mestrado em Antropologia Social) - Programa de Pós-Graduação em Antropologia Social do Museu Nacional da Universidade Federal do Rio de Janeiro, Rio de Janeiro, 1987. Disponível em: <http://nmspp.net.br/arquivos/para_leitura/conflitos_no_campo_ no_rj/Mobilizacao $\% 20$ camponesa $\% 20$ e $\% 20$ competicao $\% 20$ politica $\% 20$ no $\% 20$ estado $\% 20$ do\%20Rio\%20de\%20Janeiro\%201950-1964.pdf>. Acesso em: 27 ago. 2015.

HONNETH, A. Luta por reconhecimento: a gramática moral dos conflitos sociais. São Paulo: Editora 34, 2003.

MEDEIROS, L. S. de. Levantamento de conflitos no Estado do Rio de Janeiro. Dez anos de luta pela terra: 1969-1979. CEDEC/ABRA/CPDA-UFRRJ, 1983. (Relatório de Pesquisa, mimeo.). Disponível $\mathrm{em}$ : <http://www.nmspp.net.br/arquivos/para_leitura/conflitos_no_campo_no_ri/Levantamento $\% 20$ de\%20conflitos\%20-\%20Estado\%20do\%20Rio\%20de\%20Janeiro\%20-\%20Projeto\%20Dez\%20 anos\%20de\%20luta\%20pela\%20terra\%201969-1979.pdf>. Acesso em: 27 ago. 2015.

MELUCCI, A. A invençáo do presente: movimentos sociais nas sociedades complexas. Petrópolis: Vozes, 2001.

PALMEIRA, M.. Desmobilização e conflito: relaçóes entre patróes na agroindústria pernambucana. FERNANDES, B. M.; MEDEIROS, L. S. de; PAULILO, M. I. (Org.). Lutas camponesas contemporâneas: condiçóes dilemas e conquistas - o Campesinato como sujeito político (1950 a 1980). São Paulo: UNESP, 2009. v.1. p. 171-200.

SCOTT, J. C. Formas cotidianas de resistência camponesa. Raízes, Campina Grande, v. 21, n. 1, p. 10-31, jan./jun. 2002. Disponível em: <http://www.ufcg.edu.br/ raizes/artigos/Artigo_86.pdf>. Acesso em: 27 ago. 2015.

SILVEIRA-LINDOSO, M. J. R. P. da. A ambiguidade na transformaçáo: um estudo sobre ideologia. 1983. 182 f. Dissertação (Mestrado em Ciência Política) - Faculdade de Filosofia, Letras e Ciências Humanas, Universidade de São Paulo, São Paulo, 1983. 
TEIXEIRA, M. A. dos S. Conflitos por terra em diferentes configuraçóes: um estudo de caso em Magé, RJ. 2011. 231 f. Dissertação (Mestrado em Ciências) - Programa de Pós-Graduação em Ciências Sociais em Desenvolvimento, Agricultura e Sociedade, Universidade Federal Rural do Rio de Janeiro, Rio de Janeiro, 2011. Disponível em: <http://r1.ufrrj.br/cpda/wp-content/ uploads/2011/11/Disserta\%C3\%A7\%C3\%A3o_Marco_Ant\%C3\%B4nio_dos_Santos_ Teixeira_2011.pdf>. Acesso em: 27 ago. 2015.

THOMPSON, E. P. A formaçáo da classe operária inglesa. A árvore da liberdade. Rio de Janeiro: Paz e Terra, 1987. v. 1.

Costumes em comum: estudos sobre a cultura popular e tradicional. São Paulo: Companhia das Letras, 1998.

WEID, E. Von der; BASTOS, Ana Marta Rodrigues. O fio da meada. Estratégia de expansão de uma indústria têxtil: Companhia América Fabril: 1878-1930. Rio de Janeiro: Fundação Casa de Rui Barbosa; Confederação Nacional da Indústria, 1986.

\section{Forms of collective action: thoughts on the land disputes in Magé, Rio de Janeiro}

\section{Abstract}

This paper aims to discuss certain forms of collective action used by a group of rural workers who were threatened with eviction of the land they lived in. The analysis is based on land conflicts involving settlers and grabbers of two farmlands: América Fabril and Fazenda Conceição de Suruí, both in Magé, a district in the state of Rio de Janeiro. Most of the dispute - between 1960 and 1970 - was during the civil-military dictatorship, a period considered by scholars as a moment of political demobilization. The case stands out among the other land conflicts because of the legal land expropriation achieved by the group of rural workers in 1973 and 1974, respectively. Also, these were the only land expropriations, based on conflicts, between the 1964 coup and the late 1970s so far noticed.

Keywords: Collective action. Rural workers. Land conflicts. Civil-military dictatorship. Rio de Janeiro. 